\title{
Bahasa Sebagai Alat Komunikasi Dalam Kehidupan Manusia
}

\author{
Okarisma Mailani ${ }^{1}$, Irna Nuraeni ${ }^{2}$, Sarah Agnia Syakila ${ }^{3}$, Jundi Lazuardi ${ }^{4}$ \\ 1,2,3,4Prodi IImu Komunikasi, Fakultas IImu Komunikasi, Universitas Islam Nusantara
}

\begin{tabular}{|c|c|}
\hline ARTICLE INFO & ABSTRACT \\
\hline $\begin{array}{r}\text { Article history: } \\
\text { Received Sep 9, } 2021 \\
\text { Revised Sep 20, } 2021 \\
\text { Accepted Jan 11, } 2022\end{array}$ & \multirow{2}{*}{$\begin{array}{l}\text { Humans need communication to help survival, one of which is by using } \\
\text { language as a means of communication. Language is the most } \\
\text { effective communication tool in conveying messages, thoughts, } \\
\text { feelings, goals to others and allows for creating cooperation between } \\
\text { humans. So that the role of language becomes very dominant in } \\
\text { various human daily activities. The purpose of this study is to describe } \\
\text { matters relating to language as a means of communication and } \\
\text { communication in everyday life. The method used in this research is } \\
\text { the literature review method, the data are collected from relevant } \\
\text { literature data. The result of this research and discussion is to explain } \\
\text { about language as a communication tool which discusses the function } \\
\text { of language as a human communication tool which includes five basic } \\
\text { functions, namely the function of expression, the function of } \\
\text { information, the function of exploration, the function of persuasion, and } \\
\text { the function of entertainment. And explain about communication in } \\
\text { everyday life which discusses why we communicate and the language } \\
\text { used when communicating in everyday life. As social beings, of course } \\
\text { humans in their lives need communication to be able to establish } \\
\text { relationships with other humans. Language is the most effective tool or } \\
\text { medium for conveying thoughts, with human language being able to } \\
\text { interact and talk about anything. For this reason, every human being } \\
\text { communicates to get or convey information or messages. }\end{array}$} \\
\hline \multirow[t]{3}{*}{$\begin{array}{r}\text { Language; } \\
\text { Communication Tool; } \\
\text { Human. }\end{array}$} & \\
\hline & ABSTRAK \\
\hline & $\begin{array}{l}\text { Manusia membutuhkan komunikasi untuk membantu kelangsungan } \\
\text { hidup, salah satunya dengan menggunakan bahasa sebagai alat } \\
\text { komunikasi. Bahasa merupakan alat komunikasi yang paling efektif } \\
\text { dalam menyampaikan pesan, pikiran, perasaan, tujuan kepada orang } \\
\text { lain dan memungkinkan untuk menciptakan kerja sama antar manusia. } \\
\text { Sehinga peran bahasa menjadi sangat dominan dalam berbagai } \\
\text { aktivitas keseharian manusia. Tujuan dari penelitian ini yaitu untuk } \\
\text { mendeskripsikan hal-hal yang berkaitan dengan bahasa sebagai alat } \\
\text { komunikasi dan komunikasi dalam kehidupan sehari-hari. Metode yang } \\
\text { digunakan dalam penelitian ini yaitu metode kajian pustaka, data } \\
\text { dihimpun dari data-data kepustakaan yang relevan. Hasil dari } \\
\text { penelitian dan pembahasan ini adalah menjelaskan tentang bahasa } \\
\text { sebagai alat komunikasi yang didalamnya membahas tentang fungsi } \\
\text { bahasa sebagai alat komunikasi manusia yang mencakup lima fungsi } \\
\text { dasar, yaitu fungsi ekspresi, fungsi informasi, fungsi eksplorasi, fungsi } \\
\text { persuasu, dan fungsi enterteimen. Dan menjelaskan tentang } \\
\text { komunikasi dalam kehidupan sehari-hari yang didalamnya membahas } \\
\text { tentang mengapa kita berkomunikasi dan bahasa yang digunakan } \\
\text { ketika berkomunikasi dalam kehidupan sehari-hari. Sebagai makhluk } \\
\text { sosial, tentu manusia dalam kehidupannya membutuhkan komunikasi } \\
\text { untuk dapat menjalin hubungan dengan manusia lainnya. Bahasa } \\
\text { menjadi alat atau media paling efektif untuk menyampaikan isi pikiran, } \\
\text { dengan bahasa manusia dapat berinteraksi dan berbicara mengenai } \\
\text { apa saja. Untuk itu setiap manusia melakukan komunikasi untuk } \\
\text { mendapatkan atau menyampaikan informasi atau pesan. }\end{array}$ \\
\hline
\end{tabular}

This is an open access article under the CC BY-NC license.

(c) (i) (5)




\section{Corresponding Author:}

Okarisma Mailani,

Prodi IImu Komunikasi, Fakultas IImu Komunikasi,

Universitas Islam Nusantara,

Jl. Soekarno-Hatta No.530, Sekejati, Kota Bandung, Jawa Barat 40286

Email: Ocafillah@gmail.com

\section{PENDAHULUAN}

Alat komunikasi yang paling handal ampuh dalam kehidupan bersama dalam suatu masyarakat adalah bahasa. Manusia memakai bahasa dalam seluruh kesehariannya. Bahasa menjadi begitu penting dalam keseluruhan hidup manusia. Jika penggunaan bahasa secara minimal dapat dipahami sesuai maksud dan tujuan dari si pembicara maka bahasa sudah mencapai tujuan dalam menyampaikan sebuah pesan dalam komunikasi. Dalam kondisi resmi, seluruh pembicaraan harus mengikuti pola-pola tertentu. Dalam mempelajari maksud dan tujuan tertentu di dalam berkomunikasi baik secara lisan atau pun tulisan, konteks utama yang perlu diperhatikan oleh penutur adalah tujuan berbahasa dapat tercapai atau mencapai tujuan.

Bahasa lisan ataupun bahasa tulisan secara bersama-sama dan terus-menerus sangat berpengaruh terhadap seluruh hidup manusia. Sering kali bahasa lisan, kalau didengar oleh pendengar, maknanya menjadi bias, demikian juga bahasa tulisan kalau dibaca oleh seseorang, maknanya juga menjadi bias karena pembaca kurang memahami apa yang tersirat dan tersurat di dalam tulisan tersebut (Meinawati, Harmoko, Rahmah, \& Dewi 2020). Dengan kata lain, logika berpikir secara baik dan benar bisa melenceng keluar dari makna sesungguhnya dari kata atau kalimat yang terbangun dalam bentuk dan isi dari tulisan atau ulang tutur dari bahasa lisan yang dimaksud oleh penutur dan penulis.

Bahasa adalah sebuah sarana untuk berkomunikasi. Bahasa juga sebagai sarana untuk menyampaikan, pendapat, dan argumentasi kepada pihak lainnya. Karena itu, bahasa memiliki peran sosial penting dalam berkomunikasi dengan masyarakat luas (Adolf Hualai, 2017: 7 dan Gorys Keraf, 1994: 3). Dalam proses berkomunikasi seorang komunikator maupun komunikan membutuhkan kemampuan berbahasa agar dapat memahami isi pembicaraan. Mereka berhutang pada bahasa untuk membedah dan membedakan setiap problem sosial dalam proses berkomunikasi. Bahasa selalu tunduk pada penggunanya. Di sinilah aspek bahasa memainkan peran yang sangat penting di dalam berkomunikasi.

Bahasa dan komunikasi memiliki hubungan yang sangat erat. Hubungan keduanya tercermin dalam pengertian bahasa menurut rumusan linguistik dan tinjauan komunikasi, yaitu bahasa sebagai alat atau media komunikasi yang digunakan oleh manusia dalam berinteraksi dengan sesamanya. Sebaliknya komunikasi, membutuhkan media yaitu bahasa. Noermanzah (2017: 2) menjelaskan bahwa Bahasa adalah suatu pesan yang biasanya disampaikan dalam bentuk ekspresi sebagai alat komunikasi dalam berbagai kegiatan tertentu. Menurut KBBI (Kamus Besar Bahasa Indonesia), bahasa adalah sistem lambang bunyi yang arbiter, yang digunakan oleh sekelompok masyarakat untuk bekerjasama, berinteraksi, dan juga untuk mengidentifikasikan diri. Dilihat dari pengertian yang ada dalam kamus tersebut, dapat dipahami bahwa bahasa juga dapat berfungsi sebagai lambang bunyi sebagai mana not yang ada pada nada, akan tetapi fungsi atau manfaat yang diberikan sangatlah berbeda antara keduanya.

Disadari atau tidak sebagian besar tindakan manusia dalam berkomunikasi termasuk tindakan politik, sosial, hukum, dan pendidikan sangat kental dipengaruhi oleh bahasa. Peran bahasa menjadi sangat dominan dalam berbagai aktivitas keseharian manusia, tidak ada tindakan tanpa bahasa. Bahasa menciptakan makna dan nilai yang diyakini dan dijadikan pedoman hidup. Sejarah peradaban dunia sebenarnya adalah sejarah bahasa. Filsuf Yunani kuno seperti Aristoteles mulai menyadari fungsi bahasa sebagai alat untuk mencari dan mengungkap kebenaran. Seluruh tindakan manusia yang diungkapkan lewat bahasa dapat dipahami melalui komunikasi. Dengan demikian yang ditekankan di sini adalah penggunaan bahasa dalam proses komunikasi.

Bahasa berperan sentral dalam membangun hampir seluruh informasi dan komunikasi. Dalam berkomunikasi setiap bangsa memiliki budaya dan karakter berbeda-beda yang 
berpengaruh terhadap kegiatan berbahasa sehari-hari (Bustomi, 2019). Penggunaan bahasa berpengaruh pada budaya bangsa dalam berpikir, bertindak, dan berperi laku. Bahasa dapat membawa perubahan yang baik bagi seluruh unsur yang ada di dalam komunikasi. Devianty (2017) mengatakan bahwa dalam komunikasi bahasa pun dapat digunakan sesuai konteks dan kedudukan secara baik dan benar. Berbagai dimensi dan perspektif bahasa dalam berbagai situasi dan kondisi pada saat berkomunikasi ini, menjadikan kajian bahasa menjadi semakin dinamis dan semakin kompleks.

Bahasa adalah suatu bagian yang tidak dapat dipisahkan dari kehidupan manusia. Ketika sedang berkomunikasi Bahasa mempunyai peran yang penting. Bahasa menjadi sebuah alat dalam komunikasi yang mana Bahasa dan komunikasi ini memiliki hubungan yang tidak dapat dipisahkan, karena bahasa digunakan sebagai alat komunikasi untuk mengungkapkan pikiran dan perasaan seseorang kepada orang lain. Penggunaan Bahasa yang baik itu akan memudahkan orang yang kita ajak berkomunikasi mengerti dengan apa yang kita bicarakan dan itu akan berdampak pada jalannya komunikasi yang dilakukan. Pengertian Bahasa itu meliputi dua bidang. Pertama, bunyi yang dihasilkan oleh alat ucap dan arti atau makna yang terkandung dalam bunyi itu sendiri. Bunyi itu merupakan getaran yang mendorong alat pendengaran kita. Kedua, arti atau makna yang terkandung di dalam arus bunyi itu mengakibatkan adanya reaksi terhadap suatu hal yang di dengarkannya. Untuk selanjutnya, arus bunyi itu disebut dengan arus ujaran (Ritonga, 1:2010).

Setiap bunyi yang dihasilkan oleh alat ucap manusia belum bisa dikatakan bahasa bila tidak terkandung makna di dalamnya. Apakah setiap arus ujaran mengandung makna atau tidak, haruslah dilihat dari konvensi suatu kelompok masyarakat tertentu. Setiap kelompok masyarakat bahasa, baik kecil maupun besar secara konvensional telah sepakat bahwa setiap struktur bunyi ujaran tertentu akan mempunyai arti tertentu pula. Dengan demikian, terhimpunlah bermacammacam susunan bunyi yang satu berbeda dengan yang lain, yang masing-masing mengandung suatu maksud tertentu di dalam suatu masyarakat bahasa.

Bahasa merupakan komponen terpenting dalam kehidupan manusia. Manusia tidak akan bisa melanjutkan kelangsungan hidup mereka dengan baik dan teratur tanpa adanya bahasa. Mereka tidak bisa berinteraksi dengan mudah dan baik jika mereka tidak menguasai bahasa antara satu sama lain dan dengan tidak adanya kesinambungan tersebut mereka juga tidak dapat menangkap ekspresi kejiwaan maupun keinginan yang diutarakan oleh lawan komunikasinya. Hal ini juga yang menyebabkan adanya sekat dan kurang terkaitnya emosional satu sama lain. Bahasa sebagai alat komunikasi mempunyai peranan penting dalam interaksi manusia. Bahasa dapat digunakan manusia untuk menyampaikan ide, gagasan, keinginan, perasaan dan pengalamannya kepada orang lain. Bahasa adalah salah satu bentuk perwujudan peradaban dan kebudayaan manusia, dalam kamus linguistik, bahasa adalah satuan lambang bunyi yang arbitrer yang digunakan oleh suatu anggota masyarakat untuk bekerja sama, berinteraksi dan mengidentifikasi diri (dalam Susanti, 2012).

Bahasa adalah identitas dari suatu negara sebagai alat untuk berkomunikasi. Setiap orang membutuhkan bahasa ketika berinteraksi, mengungkapkan ide dan pendapat serta hubungan sosial lainnya (Prasasti, 2016). Asal muasal bahasa berawal dari warisan masyarakat dan bagian dari tradisi masyarakat yang sangat penting dalam kehidupan bermasyarakat, mereka telah mengadakan jalinan hubungan erat antara dua bahasa atau lebih sering menimbulkan adanya gejala dua bahasa. Sehingga bahasa dalam masyarakat berkecenderungan untuk menguasai beberapa bahasa selain bahasa lokalnya. Bahasa memiliki fungsi penting dalam kehidupan bermasyarakat khususnya dalam berinteraksi dan berkomunikasi.

Bahasa sangat erat hubungannya dengan masyarakat penggunanya (Hariadi, 2014). Setiap bangsa memiliki keunikan yang berbeda satu sama lain. Tidak ada satupun bahasa di dunia ini yang sama. Sehingga kita tidak bisa menyalahkan dan memaksa setiap orang harus memakai bahasa Indonesia selamanya. Sebagai manusia dimuka bumi, pastinya mempunyai bahasa yang digunakan untuk berkomunikasi bahkan memiliki ragam yang bervariasi, hal ini tergantung dengan sudut pandang yang digunakan bahasa itu. Sudut pandang yang dimaksud yaitu waktu dan tempat, pembicara-pendengar, topik yang dibicarakan, tujuan yang akan dicapai.

Bahasa itu penting untuk dipahami apabila ingin meningkatkan empat keterampilan Bahasa, diantaranya yaitu: berbicara, membaca, menulis dan menyimak (Noermanzah dkk., 2018: 
172). Dengan menguasai keterampilan bahasa tersebut kita sudah mampu berkomunikasi dengan baik serta mampu melakukan perubahan terhadap diri sendiri, masyarakat maupun bangsa. Terlebih saat ini kita dituntut untuk menggunakan Bahasa untuk berkomunikasi dengan baik, santun, dan kreatif. Untuk itu, pentingnya mempelajari Bahasa bukan hanya sebagai alat komunikasi, tetapi sebagai citra pikiran dan kepribadian.

Komunikasi tidak hanya terbatas pada bahasa verbal, tetapi ada beberapa ahli berpendapat bahwa ketika terdapat beberapa orang bersama dalam suatu tempat, pasti terjadi komunikasi. Walaupun kita tidak sedang berbicara, namun hal ini termasuk kedalam bentuk lain dari komunikasi yang bisa diekspresikan melalui bahasa tubuh, ekspresi wajah, dan suara-suara non-linguistic (contohnya itu seperti menggerutu). Komunikasi merupakan perpindahan suatu makna melalui suara, tanda, bahasa tubuh dan simbol. Bahasa adalah sistem simbol yang teratur untuk memindahkan makna tersebut. Dengan demikian, Bahasa adalah suatu perubahan komunikasi yang terdiri dari sistem simbol khusus yang disampaikan oleh sekelompok orang berupa ide dan informasi (Fridani, L 2014).

Manusia memerlukan bahasa sebagai alat berkomunikasi. Bahasa sebagai alat komunikasi, memegang peranan yang sangat penting dalam kehidupan manusia karena dengan bahasa manusia dapat berinteraksi dan berbicara mengenai apa saja. Berdasarkan cara penyajiannya bahasa dibedakan menjadi dua sarana, yaitu sarana dengan bahasa tulis dan bahasa lisan, Baik bahasa lisan atau bahasa tulis salah satu fungsinya adalah untuk berkomunikasi sehingga mempengaruhi interaksi sosial dalam masyarakat dapat terjalin. Bahasa lisan antara daerah satu dengan daerah lain berbeda yang disebut dengan dialek. Guna menyatukan bahasa dimasyarakat dari beberapa daerah, diperlukan bahasa nasional. Darjdowidjodjo (dalam Susanti, 2012) berpendapat bahwa pemakaian bahasa berkaitan dengan praktik pengetahuan bahasa. Semakin luas pengetahuan bahasa yang digunakan dalam komunikasi, semakin meningkat kemampuan keterampilan dalam memberi makna suatu kata atau kalimat.

Dalam berkomunikasi manusia cenderung memilih kata-kata tertentu untuk mencapai tujuannya. Pemilihan kata-kata tersebut bersifat strategis Dengan demikian, kata yang diucapkan, simbol yang diberikan, dan intonasi pembicaraan tidaklah semata-mata sebagai ekspresi pribadi atau cara berkomunikasi, tetapi dipakai dengan sengaja untuk maksud tertentu. Menurut Chaer (dalam Diah \& Wulandari, 2015), Fungsi bahasa sebagai alat komunikasi manusia mencakup lima fungsi dasar, yaitu fungsi ekspresi, fungsi informasi, fungsi eksplorasi, fungsi persuasi dan fungsi entertainmen. Bahasa juga berfungsi sebagai alat berkomunikasi antara anggota masyarakat. Fungsi tersebut digunakan dalam berbagai lingkungan, tingkatan, dan kepentingan yang beraneka ragam, misalnya: komunikasi ilmiah, komunikasi bisnis, komunikasi kerja, dan komunikasi sosial, dan komunikasi budaya (Susilo, 2014).

Dardjowidjoyo (dalam Diah \& Wulandari, 2015) menjelaskan bahwa kemampuan berbahasa merupakan ciri khusus manusia, bahkan sebelum manusia bisa bicara ia sudah bisa berbahasa sesuai dengan pendapat Kridalaksana (dalam Suardi et al, 2019) bahasa merupakan alat komunikasi yang diperoleh manusia sejak lahir. Menurut Astuti et al (2012), bahasa pada prinsipnya merupakan alat untuk berkomunikasi dan alat untuk menunjukkan identitas masyarakat pemakai bahasa. Bahasa hidup dan berkembang dalam suatu masyarakat dan dipakai oleh warganya untuk berkomunikasi. Kesantunan berbahasa merupakan keterampilan yang harus dimiliki oleh setiap manusia guna berinteraksi dan berkomunikasi dengan orang lain. Keterampilan berbahasa tersebut menjadi bagian yang sangat penting bagi setiap orang agar dapatmengemukakan pikiran dan perasaannya secara baik dan menyeluruh.

\section{METODE PENELITIAN}

Metode yang digunakan dalam penelitian ini adalah menggunakan metode kajian pustaka atau kajian literatur. Kajian Pustaka merupakan daftar referensi dari semua jenis referensi seperti buku, jurnal papers, artikel, disertasi, tesis, skripsi, hand outs, laboratory manuals, dan karya ilmiah lainnya. Menurut Pohan (2007: 42), kegiatan ini (penyusunan kajian pustaka) bertujuan mengumpulkan data dan informasi ilmiah, berupa teori-teori, metode, atau pendekatan yang pernah berkembang dan telah di dokumentasikan dalam bentuk buku, jurnal, naskah, catatan, rekaman sejarah, dokumen-dokumen, dan lain-lain yang terdapat di perpustakaan. Sedangkan 
menurut Sugiyono (2017: 291) Studi Kepustakaan merupakan langkah yang penting dimana setelah seseorang peneliti menetapkan topik penelitian, langkah selanjutnya adalah melakukan kajian teoritis dan referensi yang terkait dengan penelitian yang dilakukan. Dalam penelitian bahasa sebagai alat komunikasi berusaha untuk mendeskripsikan hal-hal yang berkaitan dengan bahasa sebagai alat komunikasi yang didalamnya menjelaskan fungsi bahasa sebagai alat komuniksi, dan komunikasi dalam kehidupan sehari-hari yang didalamnya menjelaskan mengapa kita berkomunikasi, dan bahasa yang digunakan ketika berkomunikasi dalam kehidupan seharihari.

\section{HASIL DAN PEMBAHASAN}

Bahasa sebagai Alat Komunikasi, Bahasa sebagai alat komunikasi merupakan cara yang paling efektif untuk menyampaikan pikiran, maksud maupun tujuan kepada orang yang kita ajak berkomunikasi. Pada saat menggunakan bahasa untuk berkomunikasi, itu memiliki tujuan agar bisa menarik perhatian pendengar ataupun pembaca. Manusia memiliki dua cara saat berkomunikasi, yaitu verbal dan non-verbal. Berkomunikasi secara verbal itu biasanya dilakukan dengan menggunakan alat atau media baik berupa lisan maupun tulisan, sedangkan berkomunikasi secara non-verbal itu biasanya dilakukan dengan menggunakan media berupa simbol contohnya seperti tanda lalu lintas kemudian diterjemahkan kedalam bahasa manusia.

Kemampuan manusia dalam berbahasa, itu yang membedakannya dari makhluk sosial lainnya, merupakan akibat dari pembesaran dan perkembangan otak manusia. Salah satu pandangan menyebutkan bahwa orang-orang yang hidup di berbagai belahan dunia merasa perlu untuk bisa mengatur solusi dalam memecahkan masalah yang mereka hadapi. Dalam hal ini, mereka menciptakan berbagai cara hidup dan bersama hal itu, bahasa menjadi salah satu cara untuk memenuhi kebutuhan mereka. Fungsi Bahasa yang paling dasar adalah untuk menamai atau menjuluki orang, objek ataupun peristiwa. Setiap orang punya nama untuk identifikasi sosial. Orang juga dapat menamai apa saja, misalnya objek-objek yang berlainan, termasuk perasaan tertentu yang mereka alami atau rasakan.

Bahasa sebagai sarana komunikasi mempunyai fungsi utama bahasa adalah bahwa komunikasi ialah penyampaian pesan atau makna oleh seseorang kepada orang lain. Keterikatan dan keterkaitan bahasa dengan manusia menyebabkan bahasa tidak tetap dan selalu berubah seiring perubahan kegaiatan manusia dalam kehidupannya di masyarakat. Menurut Chaer (dalam Diah \& Wulandari, 2015), Fungsi bahasa sebagai alat komunikasi manusia mencakup lima fungsi dasar, yaitu fungsi ekspresi, fungsi informasi, fungsi eksplorasi, fungsi persuasi dan fungsi entertainmen. (a). Fungsi Ekspresi mewadahi konsep bahwa bahasa merupakan media manusia untuk melahirkan ungkapan-ungkapan batin yang ingin disampaikan penutur kepada orang lain. (b). Fungsi Informasi adalah fungsi untuk menyampaikan pesan atau amanat kepada orang lain. (c). Fungsi Eksplorasi adalah penggunaan bahasa untuk menjelaskan suatu hal, perkara dan keadaan. (d). Fungsi Persuasi adalah penggunaan bahasa yang bersifat mengajak atau mempengaruhi. (e). Fungsi Entertainmen adalah penggunaan bahasa untuk menghibur, menyenangkan dan memuaskan batin. Kelima fungsi ini sangat mendukung proses pengembangan ilmu pengetahuan, terutama fungsi informasi dan fungsi eksplorasi.

Sedangkan menurut Book (dalam Deddy Mulyana, 2017), mengemukakan agar komunikasi yang dilakukan itu berhasil, sekurang-kurangnya Bahasa harus memenuhi tiga fungsi utama, diantaranya yaitu: (a). Fungsi yang pertama yaitu untuk mengenal dunia yang ada di lingkungan sekitar kita, melalui Bahasa kita mempelajari apa saja yang menarik minat dan perhatian kita. Kita bisa berbagi pengalaman, bisa dari peristiwa masa lalu yang kita alami sendiri, maupun dari informasi atau pengetahuan yang kita dapatkan dari sumber kedua, misalnya dari media cetak ataupun media elektronik. Kita juga menggunakan Bahasa untuk memperoleh dukungan atau persetujuan dari orang lain mengenai pengalaman atau pendapat kita. Melalui Bahasa pula kita bisa memprediksi apa yang akan mereka katakan. (b). Fungsi kedua yaitu sebagai sarana untuk berinteraksi satu sama lainnya, dan dengan bahasa manusia akan mudah bersosialisasi antar sesama. Artinya, Bahasa yang kita gunakan itu untuk memperoleh kesenangan dan keselarasan dalam berhubungan dengan sesama manusia sebagai makhluk sosial. Dan juga dengan Bahasa kita bisa mengendalikan lingkungan kita, termasuk orang-orang yang ada di sekitar kita. (c). Fungsi yang ketiga menjadikan hidup manusia menjadi lebih baik dan teratur. Dengan keteraturan tersebut, manusia bisa mengenal diri mereka sendiri, muncul sikap 
saling membutuhkan dan memahami terhadap kepercayaan yang mereka miliki serta mereka dapat menyusun tujuan hidup yang jelas untuk menempuh kehidupan mereka yang lebih baik dan teratur.

Oleh karena itu, setiap manusia mempunyai kewajiban untuk memahami dan menggunakan Bahasa dalam kehidupannya sehari-hari seperti tiga fungsi tersebut. Untuk itu, Bahasa ada bukan untuk saling mengejek, menyinggung, atau memaki, antar sesama. Tetapi, Bahasa dianugerahi oleh Tuhan kepada manusia untuk saling mengenal, saling memuji, mengajak serta memberikan saran dan kritik antar sesama manusia. Yang memiliki tujuan agar kehidupan manusia ini akan terus berlangsung dengan baik, tertib, teratur dan penuh kedamaian.

Setiap kalimat yang di ucapkan manusia kepada sesamanya selalu ada maksud khusus tersendiri, sehingga kita tahu adanya jenis-jenis kalimat yang diantaranya kalimat untuk bertanya, kalimat untuk memberikan informasi atau kalimat pemberitahuan, kalimat peringatan dan lain-lain. Menurut Mar"at (2012: 31) menyatakan bahwa "apabila pendengar gagal menangkap fungsi-fungsi (misal: kalimat sebagai menyuruh, memerintah, dan sebagainya), maka dikatakan dia salah mengerti." Untuk menjelaskan hal tersebut, Mar"at menjelaskan tiga aspek penting dari fungsi bahasa, yaitu: (a). Speech Act, Atau bisa juga bisa disebut "tindak tutur", hal ini sangat mempengaruhi fungsi bahasa dalam bahasa lisan. Speech Act ini menjadi salah satu acuan bagi lawan tutur atau pendengar, dalam menangkap dan memaknai maksud fungsi kalimat yang disampaikan pembicara. (b). Propositional Content, Secara garis besarnya Propositional Content merupakan isi yang terkandung dalam pesan yang disampaikan pembicara pada lawan bicaranya. Propositional Content inilah yang harus bisa ditangkap pendengar terkait maksud dan makna yang didengarnya. (c). Thematic Strukture, Merupakan penilaian tentang keadaan mental pendengar saat mendengarkan pembicara. Pembicara dalam hal ini dituntut mememikirkan, kirakira apa yang dipikirkan pendengar saat mendengarkan si pembicara itu berbicara. Saat melakukan percakapan pembicaralah yang harus mengarahkan. Karena fungsi Thematic Strukture yakni untuk menyampaikan informasi baru dan lama serta memperjelas komponen pembentuk suatu kalimat (subjek, predikat, kerangka, ataupun sisipan).

Dengar ketiga aspek di atas, maka fungsi suatu kalimat sebagai kebutuhan manusia sehari-hari dalam berkomunikasi dan bersosialisasi dapat terpenuhi dengan baik dan berjalan dengan lancar tanpa sering terjadi suatu kesalah pahaman antar individu saat berkomunikasi. Manusia memiliki ranah kehidupan yang sangat luas, sehingga tidak jarang jika kita membicarakan fungsi bahasa juga sangat banyak tergantung situasi dan tempat bahasa itu digunakan. Selain fungsi di atas, fungsi bahasa secara umum sebagai identitas diri, pemersatu wilayah, sebagai alat untuk berpikir, dan lain sebagainya.

Komunikasi dalam Kehidupan Sehari-hari, Komunikasi dalam kehidupan sehari-hari sangatlah penting. Manusia tidak dapat menghindari berbagai macam bentuk komunikasi karena dengan komunikasi manusia dapat membangun relasi yang dibutuhkannya sebagai makhluk sosial. Komunikasi adalah sebuah proses pertukaran atau penyampaian pesan antar individu, baik itu dilakukan dengan bahasa, simbol-simbol, sinyal-sinyal maupun dengan perilaku atau tindakan yang ditujukan dari seseorang ke orang lain. Proses penyampaian pesan menggunakan cara yang efektif akan dapat mudah dipahami oleh penerima pesan. Penyampaian pesan ini dapat berupa isyarat, lisan, maupun tulisan. Dapat dikatakan bahwa dalam berkomunikasi dibutuhkan kemampuan komunikasi yang baik sehingga tujuan yang akan disampaikan dapat diterima dan dipahami dengan baik oleh penerima pesan. Dalam Kamus Bahasa Indonesia, komunikasi diartikan sebagai pengiriman dan penerimaan pesan atau berita antara dua orang atau lebih sehingga pesan yang dimaksud dapat dipahami.

Thomas M. Scheidel (dalam Deddy Mulyana 2001), menjelaskan kita berkomunikasi untuk menyatakan dan mendukung identitas diri, membangun kontak sosial dengan orang yang berada di sekitar kita, mempengaruhi orang, namun tujuan utama dalam komunikasi adalah mengendalikan lingkungan fisik dan psikologi kita. Sedangkan menurut Gordon L. Zimmerman (dalam Deddy Mulyana 2001), membagi tujuan komunikasi dalam dua hal besar. Pertama, komunikasi digunakan untuk menyelesaikan tugas-tugas yang penting bagi kebutuhan kita, disini terjadi pertukaran informasi yang diperlukan untuk menyelesaikan tugas. Kedua, berkomunikasi untuk berhubungan dengan orang lain, terjadi pertukaran informasi mengenai bagaimana hubungan kita dengan orang lain. Untuk itu setiap manusia melakukan komunikasi untuk 
mendapatkan maupun menyampaikan informasi. Berkomunikasi akan memungkinkan manusia untuk menanggapi, menyusun dan mengungkapkan segala sesuatu yang ada disekitarnya sebagai bahan komunikasi.

Apa yang mendorong manusia sehingga ingin berkomunikasi dengan manusia lainnya? Teori dasar Biologi menyebutnya adanya dua kebutuhan, yakni kebutuhan untuk mempertahankan kelangsungan hidupnya dan kebutuhan untuk menyesuaikan diri dengan lingkungannya. Harold D. Laswell salah seorang peletak dasar ilmu komunikasi lewat ilmu politik menyebut tiga fungsi dasar yang menjadi penyebab, mengapa manusia perlu berkomunikasi yaitu: (a). Pertama, adalah hasrat manusia untuk mengontrol lingkungannya. Melalui komunikasi manusia dapat mengetahui peluang yang ada untuk dimanfaatkan, dipelihara dan menghindar pada hal-hal yang mengancam alam sekitarnya. Melalui komunikasi manusia dapat mengetahui suatu kejadian atau peristiwa. Bahkan melalui komunikasi manusia dapat mengembangkan pengetahuannya, yakni belajar dari pengalamannya, maupun melalui informasi yang mereka terima dari lingkungan sekitarnya. (b). Kedua, adalah upaya manusia untuk dapat beradaptasi dengan lingkungannya. Proses kelanjutan suatu masyarakat sesungguhnya tergantung bagaimana masyarakat itu bisa beradaptasi dengan lingkungannya. Penyesuaian disini bukan saja terletak pada kemampuan manusia memberi tanggapan terhadap gejala alam seperti banjir, gempa bumi dan musim yang mempengaruhi perilaku manusia, tetapi juga lingkungan masyarakat tempat manusia hidup dalam tantangan. Dalam lingkungan seperti ini diperlukan penyesuaian, agar manusia dapat hidup dalam suasana yang harmonis. (c). Ketiga, adalah upaya untuk melakukan transformasi warisan sosialisasi. Suatu masyarakat yang ingin mempertahankan keberadaannya, maka anggota masyarakatnya dituntut untuk melakukan pertukaran nilai, perilaku, dan peranan. Misalnya bagaimana orangtua mengajarkan tatakrama bermasyarakat yang baik kepada anak-anaknya. Bagaimana sekolah difungsikan untuk mendidik warga negara. Bagaimana media massa menyalurkan hati nurani khalayaknya, dan bagaimana pemerintah dengan kebijaksanaan yang dibuatnya untuk mengayomi kepentingan anggota masyarakat yang dilayaninya.

Manusia dalam kehidupannya memerlukan komunikasi untuk dapat menjalin hubungan dengan manusia lain dan lingkungan masyarakat. Komunikasi dapat dilakukan oleh manusia melalui bahasa. Menurut Chaer dan Agustina (2010: 72), bahasa yang dipergunakan dalam kehidupan sehari-hari dibedakan menjadi dua sarana, yaitu dengan bahasa lisan dan bahasa tulis. Bahasa lisan adalah suatu bentuk komunikasi yang sering dijumpai pada manusia yang menggunakan kata-kata dari berbagai macam kata yang diucapkan melalui atau menggunakan organ mulut. Sedangkan bahasa tulis adalah ragam bahasa yang digunakan melalui media tulis, jadi bahasa yang ditulis oleh seseorang di atas kertas atau buku dan dibaca oleh orang lain. Dapat disimpulkan bahwa alat yang digunakan untuk berkomunikasi dalam kehidupan sosial di setiap harinya adalah bahasa lisan. Bahasa dapat menjadi ciri dari setiap orang yang mengujarkannya. Hubungan bahasa dengan kehidupan sosial menimbulkan interaksi antar makhluk hidup.

Bahasa adalah alat untuk berkomunikasi melalui lisan (bahsa primer) dan tulisan (bahasa sekunder). Berkomunikasi melalui lisan (dihasilkan oleh alat ucap manusia), yaitu dalam bentuk symbol bunyi, dimana setiap simbol bunyi memiliki cirri khas tersendiri. Suatu simbol bisa terdengar sama di telinga kita tapi memiliki makna yang sangat jauh berbeda. Misalnya kata 'sarang' dalam bahasa Korea artinya cinta, sedangkan dalam bahasa Indonesia artinya kandang atau tempat. Tulisan adalah susunan dari simbol (huruf) yang dirangkai menjadi kata bermakna dan dituliskan. Bahasa lisan lebih ekspresif di mana mimik, intonasi, dan gerakan tubuh dapat bercampur menjadi satu untuk mendukung komunikasi yang dilakukan. Lidah setajam pisau / silet oleh karena itu sebaiknya dalam berkata-kata sebaiknya tidak sembarangan dan menghargai serta menghormati lawan bicara / target komunikasi.

Dalam sebuah komunikasi melalui bahasa, biasanya terdapat berbagai proposisi atau berbagai ungkapan yang dapat dikaji secara lebih mendalam dalam sebuah penelitian bahasa. Pola relasi antara kata dan lingkungan sekitarnya, termasuk ruang, waktu, serta kondisi yang tepat, memungkinkan bahasa bisa menampilkan sosoknya (Sitorus, 2018). Pada bagian ini, baik bahasa lisan maupun bahasa tulisan dapat menampilkan penggunaan metafora bahasa dalam sebuah komunikasi. Pada bagian ini, bahasa (dalam artian sastra) sudah bisa tergolong berlevel tinggi dalam tingkatan penggunaan bahasa dalam berkomunikasi. Dalam berkomunikasi terdapat dua hal yang penting dalam merespons sesuatu yaitu bahasa yang tepat dan sesuai dengan kondisi yang tepat. Dalam respons itu pun yang perlu menjadi tuntutan utama adalah penggunaan bahasa yang 
tepat; kata, kalimat yang dibangun sesuai dengan situasi dan kondisi pembicara atau penutur. Hal tersebut dikemukakan oleh Jalaludin Rahmat, tentang bagaimana memahami secara tepat sebuah respon dalam berbahasa.

Pemahaman tentang ketepatan respons yang dimaksudkan adalah terjadi keserasian bahasa atau sejalannya makna pembicaraan dan respons yang mengikutinya (Devianty, 2017). Sebagai contoh seorang penutur bahasa yang bisa disebut respons $A$ harus bisa juga diikuti oleh respons $B$ yang sesuai dengan apa yang dimaksudkan dengan respons $A$. Secara normatif seperti pertanyaan harus direspons dengan jawaban, atau pun hal yang disajikan dalam sebuah bahasa lelucon, semestinya ditanggapi dengan tertawaan, atau seperti permintaan sebuah keterangan seharusnya direspons dengan memberikan sebuah penjelasan. Sebuah respons yang dibaca secara jelas, bukan hanya melalui bahasa verbal tetapi juga lewat bahasa non verbal. Jika sebuah pembicaraan yang sangat serius ditanggapi dengan santai atau main-main maka akan terjadi relasi interpersonal menjadi retak, dan akibatnya tidak terjadi peneguhan hubungan interpersonal dan disebut sebagai sebuah respons yang tidak sesuai atau tidak tepat.

Menurut Ratna Prasasti Suminar (2016) mengatakan, bahwa pemakaian bahasa Indonesia baik dalam kehidupan sehari-hari maupun dunia film mulai bergeser digantikan dengan pemakaian bahasa anak remaja yang dikenal dengan bahasa gaul. Interferensi bahasa gaul kadang muncul dalam penggunaan bahasa Indonesia dalam situasi resmi yang mengakibatkan penggunaan bahasa tidak baik dan tidak benar. Seiring perkembangan zaman khususnya di Negara Indonesia semakin terlihat pengaruh yang diberikan oleh bahasa gaul terhadap bahasa Indonesia dalam penggunaan tata bahasanya. Penggunaan bahasa gaul oleh masyarakat luas menimbulkan dampak negatif terhadap perkembangan bahasa Indonesia sebagai Identitas bangsa. Banyak masyarakat memakai bahasa gaul dan diperparah dengan generasi muda Indonesia juga tidak terlepas dari pemakaian bahasa gaul ini. Bahkan generasi muda inilah yang banyak memakai bahasa gaul daripada pemakaian bahasa Indonesia. Untuk menghindari pemakaian bahasa gaul yang sangat luas di masyarakat, seharusnya kita menanamkan kecintaan dalam diri generasi bangsa terhadap bahasa Indonesia sebagai bahasa nasional.

Harmoko (2010) mengatakan, penggunaan bahasa gaul terhadap Eksistensi Bahasa Indonesia dan berikut ini pengaruh penggunaan bahasa gaul terhadap eksistensi bahasa Indonesia. (a). Masyarakat Indonesia tidak lagi mengenal bahasa baku sehingga Kehilangan patokan dan bimbingan untuk memakai bahasa Indonesia yang Baik dan benar. (b). Masyarakat Indonesia tidak memakai lagi Ejaan Yang Disempurnakan (EYD). (c). Masyarakat Indonesia menganggap remeh bahasa Indonesia dan tidak mau mempelajari lebih lanjut karena merasa dirinya telah menguasai bahasa Indonesia yang baik dan benar. (d). Masyarakat tidak terbiasa atau justru menjadi enggan menggunakan bahasa Indonesia baku. Sementara bahasa Indonesia adalah bidang pendidikan yang harus dipahami dalam melakukan berbagai pekerjaan antara lain surat menyurat, pembicaraan resmi, tulisan akademik, dll. (e). Pudarnya rasa bangga dalam diri masyarakat Indonesia untuk dapat berkomunikasi dalam bahasa Indonesia yang baik dan benar, sementara mereka sudah terbiasa dengan bahasa pergaulan yang lazim digunakan.

Ragam bahasa Indonesia lebih memperhatikan tatanan dan kaidah kebahasaan yang baik dan benar, karena dengan menguasai bahasa Indonesia akan lebih mudah untuk berkomunikasi baik komunikasi secara lisan maupun tulis (Saddhono, 2012). Sedangkan bahasa gaul remaja memiliki beberapa keunikan yaitu; singkat, lincah dan kreatif. Pilihan katanya lebih pendek, sedangkan kata-kata yang sedikit panjang akan diperpendek melalui proses mengganti dengan kata pendek seperti "memang menjadi emang". Bahasa gaul adalah gaya bahasa yang merupakan perkembangan atau modifikasi dari berbagai macam bahasa, termasuk bahasa Indonesia sehingga bahasa gaul tidak memiliki sebuah struktur gaya bahasa yang pasti (Gunawan, 2011). Mayoritas bahasa gaul remaja yang sering keluar adalah tentang terjemahan, singkatan dan plesetan. Selain itu juga ada penambahan kata-kata yang dirasa cukup aneh jika ditelisik asal mulanya.

Pengaruh arus globalisasi dalam identitas bangsa tercermin pada perilaku masyarakat yang mulai meninggalkan bahasa Indonesia dan terbiasa menggunakan bahasa gaul (Rahayu, 2015). Zaman millineal ini sangat terlihat jelas bahwa di masyarakat sudah banyak adanya sistem penggunaan bahasa gaul, hal ini diperlakukan lagi dengan generasi muda Indonesia yang tidak terlepas dari pemakaian bahasa bebas pergaulan. Bahkan, generasi muda saat inilah yang paling 
banyak menggunakan dan menciptakan bahasa gaul di kehidupan masyarakat. Bahasa Indonesia yang baik di ruang publik akan menjadi media ampuh dalam mengajarkan penggunaan bahasa Indonesia yang benar" (Amilia, 2018), dalam pernyataan beliau penggunaan bahasa harus memperhatikan kaidah kebahasaan yang sesuai dengan perilakunya khususnya.

Maka dapat disimpulkan bahasa gaul memiliki pengaruh kuat terhadap perkembangan berbahasa Indonesia, umumnya dalam hal bertutur kata. Bahasa yang digunakan oleh remaja ini muncul dari kreativitas mengolah kata baku dalam bahasa Indonesia menjadi kata tidak baku dan cenderung tidak lazim. Pemakaian bahasa gaul dapat terlihat di iklan televisi, lirik lagu remaja, novel remaja, jejaring sosial dan lain-lain. Inilah kenyataan bahwa tumbuhnya bahasa gaul ditengah keberadaan bahasa Indonesia tidak dapat dihindari, hal ini karena pengaruh perkembangan teknologi serta pemakaiannya oleh sebagian besar remaja sehingga cepat atau lambat bahasa Indonesia akan tergeser keberadaannya.

\section{KESIMPULAN}

Bahasa sebagai alat komunikasi merupakan cara yang paling efektif untuk menyampaikan pikiran, maksud maupun tujuan kepada orang yang kita ajak berkomunikasi. Bahasa sebagai sarana komunikasi mempunyai fungsi utama bahasa adalah bahwa komunikasi ialah penyampaian pesan atau makna oleh seseorang kepada orang lain. Fungsi bahasa sebagai alat komunikasi manusia mencakup lima fungsi dasar, yaitu fungsi ekspresi, fungsi informasi, fungsi eksplorasi, fungsi persuasi dan fungsi entertainmen. Manusia memiliki ranah kehidupan yang sangat luas, sehingga tidak jarang jika kita membicarakan fungsi bahasa juga sangat banyak tergantung situasi dan tempat bahasa itu digunakan. Manusia memerlukan bahasa sebagai alat berkomunikasi. Bahasa sebagai alat komunikasi, memegang peranan yang sangat penting dalam kehidupan manusia karena dengan bahasa manusia dapat berinteraksi dan berbicara mengenai apa saja. Berdasarkan cara penyajiannya bahasa dibedakan menjadi dua sarana, yaitu sarana dengan bahasa tulis dan bahasa lisan, Baik bahasa lisan atau bahasa tulis salah satu fungsinya adalah untuk berkomunikasi sehingga mempengaruhi interaksi sosial dalam masyarakat dapat terjalin.

Komunikasi dalam kehidupan sehari-hari sangatlah penting. Manusia tidak dapat menghindari berbagai macam bentuk komunikasi karena dengan komunikasi manusia dapat membangun relasi yang dibutuhkannya sebagai makhluk sosial. Manusia dalam kehidupannya memerlukan komunikasi untuk dapat menjalin hubungan dengan manusia lain dan lingkungan masyarakat. Komunikasi dapat dilakukan oleh manusia melalui bahasa. Komunikasi digunakan untuk menyelesaikan tugas-tugas yang penting bagi kebutuhan kita, disini terjadi pertukaran informasi yang diperlukan untuk menyelesaikan tugas. Berkomunikasi juga untuk berhubungan dengan orang lain, terjadi pertukaran informasi mengenai bagaimana hubungan kita dengan orang lain. Untuk itu setiap manusia melakukan komunikasi untuk mendapatkan maupun menyampaikan informasi. Berkomunikasi akan memungkinkan manusia untuk menanggapi, menyusun dan mengungkapkan segala sesuatu yang ada disekitarnya sebagai bahan komunikasi. Dalam berkomunikasi terdapat dua hal yang penting dalam merespons sesuatu yaitu bahasa yang tepat dan sesuai dengan kondisi yang tepat. Pemahaman tentang ketepatan respons yang dimaksudkan adalah terjadi keserasian bahasa atau sejalannya makna pembicaraan dan respons yang mengikutinya.

\section{Referensi}

Aini, N. (2019, April 24). BAHASA INDONESIA SEBAGAI ALAT MEDIA KOMUNIKASI SEHARI-HARI. https://doi.org/10.31219/osf.io/dazfj

Annisa, F. N. (2020, January 4). Pemakaian Bahasa Dalam Masyarakat Tutur Kata Anak Dalam Berkomunikasi Bahasa Indonesia Di Masyarakat. https://doi.org/10.31227/osf.io/wh8e4

Arifin, E, Zaenal dan S. Amran Tasal. 2008. Cermat Berbahasa Indonesia untuk Perguruan Tinggi. Jakarta : Akademika Pressindo.

Cahyaningrum, R. W. (2019, October 29). Bahasa Indonesia Sebagai Alat Komunikasi dan Fungsi Teks dalam Pembelajaran. https://doi.org/10.31219/osf.io/yq7p6

Devianty, R. (2017). Bahasa Sebagai Cerminan Kebudayaan. Jurnal Tarbiyah, 24(2) http://jurnaltarbiyah.uinsu.ac.id/index.php/tarbiyah/article/view/167/211

F. (2019, November 5). Bahasa Indonesia Sebagai Alat Komunikasi Dan Fungsi Menulis Teks Deskripsi. https://doi.org/10.31227/osf.io/vgf83 
Fatonah, N. (2013). Fungsi Bahasa dalam Kehiduan Sehari-hari sebagai Kebutuhan Pokok Manusia. Aktivitas | Student Blog. https://blog.ub.ac.id/nimatul/files/2013/06/Artikel-Fungsi-Bahasa

Fridani, L. (2014). Hakikat Perkembangan Bahasa. Metode Pengembangan Bahasa. Jakarta: Universitas Terbuka.

Harmoko. 2010. Pengaruh Bahasa Gaul Remaja terhadap Bahasa Indonesia.

Lestari, Oktavia. (2018). Variasi Ragam Bahasa dalam Kehidupan Remaja. Working Paper. Badan Pengembangan dan Pembinaan Bahasa, Jakarta. http://repositori.kemdikbud.go.id/id/eprint/10215

Mulyana, Deddy. 2001. IImu Komunikasi. Bandung: PT Remaja Rosdakarya.

Mulyana, Deddy. 2017. Ilmu Komunikasi Suatu Pengantar. Bandung: PT Remaja Rosdakarya.

N. (2020, May 2). Bahasa sebagai Alat Komunikasi, Citra Pikiran, dan Kepribadian. https://doi.org/10.31219/osf.io/ez6dk

Purwanti, C. (2020). EKSISTENSI BAHASA DALAM KOMUNIKASI INTERPERSONAL: SEBUAH PENDEKATAN INTERDISIPLINER [LANGUAGE EXISTENCE IN INTERPERSONAL COMMUNICATION: AN INTERDICIPLINARY APPROACH]. Polyglot: Jurnal IImiah, 16(2), 266-281. doi: http://dx.doi.org/10.19166/pji.v16i2.2261

Putra, B. (2018). Bahasa Sebagai Media Utama dalam Komunikasi. https://www.kompasiana.com/bagusputra7578/5b60368cd1962e46d25d0786/bahasa-sebagaimedia-utama-dalam-komunikasi?page=all\#section1

Rahmah, D. (2019, October 29). Fungsi Bahasa Indonesia dan Fungsi Teks dalam Kehidupan Sehari-hari. https://doi.org/10.31227/osf.io/6nbz7

Sigiro, E. (2014). Pentingnya Komunikasi dalam Kehidupan Manusia. https://www.kompasiana.com/elisigiro/552af7c1f17e61145bd623cc/pentingnya-komunikasi-dalamkehidupan-manusia

Ubaidillah, A. (2016). Konsep Dasar Komunikasi Untuk Kehidupan. Jurnal Ibtida', 4(2), 30-54. http://ejournal.kopertais4.or.id/mataraman/index.php/alibtida/article/view/2987 